MAREK HENDRYKOWSKI

Instytut Filmu, Mediów i Sztuk Audiowizualnych Uniwersytet im. Adama Mickiewicza w Poznaniu

\title{
Stereotyp w przestrzeni symbolicznej
}

\begin{abstract}
Hendrykowski Marek, Stereotyp w przestrzeni symbolicznej [Stereotypes in symbolic space]. "Images" vol. XXVII, no. 36. Poznań 2020. Adam Mickiewicz University Press. Pp. 5-19. ISSN 1731-450X. DOI 10.14746/i.2020.36.01.

The subject of the article is stereotypes considered in the context of symbolic space. This redefinition and reconsideration of the complex issue of stereotypes and stereotyping of different kinds in art and everyday life aims at demonstrating the operational usefulness of this concept in contemporary humanistic reflection, including the sphere of art, everyday life and various fields of scientific research.
\end{abstract}

KEYwORDs: image, stereotype, sign, meaning, truth, lie

Zacznijmy nie od samego stereotypu, lecz ogólniej: od stereotypowości. Dostrzegalna w przekazie stereotypowość czegokolwiek, co przedstawia i bywa przedstawione, nie jest zjawiskiem incydentalnym ani fakultatywnym. Wprost przeciwnie, warto już na wstępie zauważyć, iż w dowolnie rozpatrywanym, zachodzącym przy udziale któregokolwiek z mediów czy systemów językowych procesie komunikowania należy ona do kluczowych zjawisk semantycznych, występujących obligatoryjnie.

Stereotypy jako zauważalny (uświadamiany) i niezauważalny (nieuświadamiany) współczynnik konstrukcji przekazu występują powszechnie w różnych, alternatywnych względem siebie czasoprzestrzeniach i obiegach. Komunikując się jako nadawcy i odbiorcy, co rusz natrafiamy na rozmaite stereotypy. Ilekroć zachodzi potrzeba rozpoznania oraz znakowego przedstawienia i opisania przejawów bądź aspektów najszerzej pojętej rzeczywistości, pojawia się stereotypowość jako cecha, modus i funkcja komunikatu, występując w wielu odmiennych postaciach, choć z niejednakową intensywnością wyrazu.

Istotą funkcjonowania stereotypu jest „łatwe”, symplifikujące wyobrażenie. Każdy stereotyp domaga się uznania go za coś oczywistego. Sytuuje się między nazwaniem/przedstawieniem a mniemaniem o czymś lub o kimś. Jako układ relacji tworzy skamielinę nawarstwioną w umysłach. Zalega ona i trwa w określonej czasoprzestrzeni mającej charakter symboliczny. Tkwi tam rozpostarty w ciągłym nierozładowanym napięciu pomiędzy sensem oddającym przedstawianą rzeczywistość, adekwatnym wobec niej, a uproszczeniem, uznawanym za wiarygodne przez daną zbiorowość.

Zauważmy, iż stereotypy nie służą prezentowaniu rzeczywistości, jaką ona jest, lecz ją reprezentują, stanowiąc w przekazie jej zamiennię. Ze względu na długotrwale utrwaloną niezmienność komunikowanego
Images

vol. XXVII/no. 36

Poznań 2020

ISSN 1731-450X

\section{O morfologii stereotypów}


znaczenia ich czasoprzestrzenny status ma swoją specyfikę. Upodrzędnia mianowicie rolę czasu względem przestrzeni, w której egzystują. Sferą, w której wszystko się rozgrywa, jest w przypadku każdego stereotypu sposób użycia języka jako instrumentu i systemu komunikowania.

Żaden wyraz należący do leksykalnego zasobu języka nie jest a priori stereotypem, natomiast może się nim tylko stać i bywa jego frazeologiczne użycie. System danego języka (werbalnego, gestycznego, ikonicznego, audialnego, kinematograficznego etc.) dostarcza stereotypom szeroko pojętej materii przekazu. W zależności od użytego tworzywa i od medium, które wykorzystano do ich transmisji, tak czy inaczej przejawiają się one językowo i dzieją w sferze symbolicznej. Wymagają więc od badacza umiejętności rozpoznawania struktury pojęciowej i analitycznego myślenia w kategoriach funkcji, jakie struktura ta - w jej ustereotypowionym charakterze - pełni w sferze wyobraźni społecznej.

Stereotyp "gubi się w odmęcie czasów”. Jest jak ten szlachcic z Kandyda, który może „wywieść swoje pochodzenie ledwie z siedemdziesięciu jeden pokoleń", przez co nie nadaje się na odpowiedniego szwagra w oczach potężnego pana. Ale powiadają, że mimo to spłodził syna $\mathrm{z}$ jego siostrą, przedłużywszy w ten sposób dzieje rodu ludzkiego. Trwa więc nadal, obnosząc się triumfalnie po okolicy i nic sobie nie robiąc $\mathrm{z}$ racjonalnych porządków, rozlicznych starań i wytężonych prac niestrudzenie prowadzonych w Wolteriańskim „ogródku”.

Dodajmy, iż w theatrum naszego życia codziennego stereotypowość przedstawień występuje we wszelkich odmianach komunikatów: werbalnych, niewerbalnych, słowno-obrazowych (ilustracja, fotopowieść, komiks), audialnych, ikonicznych (rysunek, rzeźba, malarstwo, grafika), gestycznych, mimicznych, fotograficznych, kinematograficznych, audiowizualnych etc. Notabene, przejawia się ona - dodajmy zaraz, iż w całkiem odmienny sposób - zarówno w pospolitych przekazach nieartystycznych, jak i w różnego typu utworach artystycznych.

Żaden $\mathrm{z}$ tych odmiennych rodzajów komunikowania $\mathrm{z}$ udziałem i wykorzystaniem stereotypów nie wyklucza drugiego. I tu, i tam, w sferze sztuki i poza jej granicami stereotyp na swój sposób występuje i zaznacza swoją obecność. Spostrzeżenie przejawów osmozy sztuki z nie-sztuką dotyczy różnorodności form przejawiania się stereotypów. Posługujemy się nimi i potrafimy je czytać, bo należą do czasoprzestrzennie określonego systemu kultury symbolicznej, która nas w życiu jednostki i zbiorowości orientuje.

Stereotypy stanowią ważny element przestrzeni symbolicznej (resp. społecznej). Na co dzień stanowią je w pierwszym rzędzie role społeczne (na przykład: matka rodu, sumienny kasjer, urodzony nauczyciel, lekarz, przedszkolanka, sędzia, przywódca, tyran, sankiulota, sufrażystka, król kurkowy, hetman, doskonała pani domu, rektor, najstarsze z rodzeństwa, primus inter pares, złota rączka). Na tym jednak nie koniec. 
Należą do nich również również: wzorce osobowe, rytuały i ceremoniały, fikcyjne figury, charakterystyki postaci wraz z ekspresją ich zachowań, wyglądem i atrybutami, zdarzenia, sytuacje i układy (samotny stróż prawa, jedyny sprawiedliwy, jeden przeciw wszystkim etc.), matryce dramatyczne i fabularne, genotypy gatunków, określony bieg akcji czy spodziewany finał historii (obowiązkowy happy end w komedii romantycznej lub też dead end w melodramacie).

Na przykłady egzemplarycznych osobowości, takich jak: Edyp, Antygona, Żołnierz Samochwał, Hamlet, Ofelia, Lady Makbet, Arlekin, Pierrot, Kolombina, Pantalone, Śpiąca Królewna, Kopciuszek, Wesoła Wdówka, słomiany wdowiec, czarny charakter, dzielny szewczyk bądź krawczyk, Donkiszot, zła królowa, macho, femme fatale, Mały Książę, upadły anioł o złotym sercu, Quasimodo, fanfaron, siłaczka, kułak, sekretarz partii, przodownik pracy, Zosia Samosia, enfant terrible, latin lover, pierwsza naiwna, Dyzio Marzyciel, chudy literat, okrutny Azjata, służąca panią, król życia, roztargniony profesor i wiele wiele innych nieustannie natrafiamy w dziełach sztuki i w realnym świecie. Granica pomiędzy rzeczywistością a sztuką w tym przypadku zaciera się, jest nieostra i umownie płynna.

Była już mowa o tym, że w procesach stereotypizacji udział biorą zarówno przekazy potoczne (nieartystyczne), jak i artystyczne. Specyficzne funkcje, jakie stereotyp pełni w kreowaniu struktur znaczeniowych tych drugich, sztuka od niepamiętnych czasów wykorzystuje z pożytkiem dla własnych celów. Niezliczoną ilość razy bywały one też przedmiotem studiów i subtelnych dociekań literaturoznawców, krytyków, teoretyków i historyków różnych dziedzin sztuki, psychoanalityków (zwłaszcza Sigmunda Freuda), estetyków, badaczy folkloru (Władimir Propp) oraz filmoznawców (Nicholas Vachel Lindsay, Hugo Münsterberg, Karol Irzykowski, Erwin Panofsky, Siegfried Kracauer, Robert Warshow i inni).

Uzbierało się na ten temat wiele zasobnych w intrygujące przykłady opracowań i publikacji. Wybór klasycznych prac z tego zakresu znajdzie Czytelnik na końcu. Większość zawartych w nich koncepcji wypada jednak mało satysfakcjonująco metodologicznie. Ich autorzy (Gordon W. Allport, Frank Keil, Ronald W. Langacker, Walter Lippmann et consortes) z reguły traktują stereotyp statycznie, w unieruchomionej postaci, jak wyodrębniony samoistny przedmiot/res, mimowiednie myląc znak z nośnikiem znaczenia.

Reifikacja pojęcia stereotypu pociąga za sobą nietrafne wyobrażenie tego, czym w istocie on jest, traktowany jako przedmiot badań, a zwłaszcza jak funkcjonuje w procesie tworzenia i deskrypcji swego znaczenia. Powiedzmy zatem: żaden stereotyp nie jest rzeczą. W procesach komunikowania, kultury i sztuki funkcjonuje on każdorazowo jako relacja semantyczna zachodząca w przestrzeni symbolicznej pomiędzy uproszczonym wyobrażeniem a ustalonym i powszechnie przyjętym w danej wspólnocie przeświadczeniem na jego temat. 
Notabene literatura dotycząca stereotypu niekoniecznie i nie zawsze bywa stricte naukowa. Miłośnik kina i krytyk filmowy Antoni Słonimski po latach zrelacjonował w swoich wspomnieniach zdarzenie zapamiętane z czasów kina niemego: „Nieraz słyszałem, jak dwunastoletni uczniak w kinie objaśniał rodzicom treść filmu. - «To jest zły charakter» - mówił uczniak. «Skąd wiesz?» - szeptem pytała matka. «No wiadomo, bo ma baczki i wąsiki» - szeptem objaśniał synek”[1].

Dowcipna wykładnia sytuacyjna zaprezentowana w relacji Słonimskiego zawiera szereg celnych spostrzeżeń dotyczących występowania stereotypów na ekranie. Najważniejszym z nich okazuje się wydobyta przez autora zależność między rozumieniem przekazu a semantycznym nacechowaniem stereotypu w procesie komunikacji. Chłopak należy do rzeszy widzów zorientowanych. Wie doskonale, że typ z baczkami i wąsikiem obligatoryjnie oznacza w panującym systemie wyobrażeń jedno, a mianowicie czarny charakter.

Matka natomiast, kinowa nowicjuszka, dopiero przyswaja sobie reguły stereotypizacji, które dla jej bywałego i już „zorientowanego" syna są czymś oczywistym. Socjolog tudzież psycholog społeczny stwierdzi, iż stereotypowa wiedza, jaką z naturalną swobodą (czytaj: bezrefleksyjnie i bezwiednie) operuje wszystkowiedzący młody kinoman, stanowi żywy dowód przynależności jednostki do pewnej grupy i będzie miał rację.

Powtórzmy: stereotyp nie jest rzeczą, lecz uogólnionym wyobrażeniem. Ani obiektywnym, ani subiektywnym, o czym za chwilę. Specyficzny status czerpie z przebiegu dokonującego się porozumienia. Nie sposób dowodzić całkowicie obiektywnego ani też subiektywnego charakteru stereotypu. Gra komunikacyjna, która toczy się wokół niego, ma charakter z istoty swej in ter subiektywny, dziejąc się umownie: $w$ relacji łączącej podmiot $z$ drugim podmiotem na zasadzie czytelnego dla obu stron uogólnienia przybierającego postać schematu poznawczego.

Stereotyp nie tkwi w języku, lecz przejawia się w uzusie językowym. Kluczowa rola w jego charakterystyce funkcjonalnej przypada stylistyce (figury stylistyczne) i frazeologii. Aby powstał, musi najpierw dojść do wytworzenia trwałej konfiguracji w polu stylistycznym, replikowanej w zbiorowym obiegu komunikacyjnym. Ma ona to do siebie, że nigdy nie zastępuje użytych elementów znakami neutralnymi stylistycznie (tzw. poziom zero stylu).

Pole semantyczne pozostaje na tyle rozległe i pojemne, iż każdorazowo mieści w sobie rezerwuar należącego doń uzusu mowy (paroles). Poszczególny wyraz „przechowuje” zatem także pamięć stereotypu. Stereotyp, choć trwały, nie jest niezmienny. Wytwarza własne alternacje, w tym zaprzeczenia. Jego przekształcenie stylistyczne może go dalece modyfikować.

[1] A. Słonimski, Wspomnienia warszawskie, Warsza-

wa 1987 , s. 46. 
Z górą sto lat temu niemiecki cesarz Wilhelm II Hohenzollern nie bez przyczyny uchodził za naczelnego agresora i podpalacza świata. W tej roli stał się propagandowym stereotypem i tak właśnie, jako zajadły wróg ludzkości i nieokrzesany teutoński barbarzyńca, był przedstawiany przez swych przeciwników w tysiącach karykatur. A przecież oprócz tego pamięć o nim funkcjonuje całkiem inaczej, nieomal życzliwie zapisana we frazie „za Wilusia” i w słynnych „kajzerkach”.

Między polem semantycznym a polem stylistycznym wyrazu wytwarza się wielorako znaczące napięcie. Słowo matka (mother, Mutter, mère) pozostaje pod względem czynnika stereotypowości przezroczyście neutralne, w odróżnieniu od mamy, mamci, mamusi, mamuśki, mamulki, maman i zestawień w rodzaju Matka Polka, matka rodu. To samo dotyczy przykładowo: ojca (ojczulka, ojcaszka, taty, tatusia, tatka, tatulka, papy, papcia), babki (babci, babuni, babcinki, babulki, babuleńki, buby, baby, Baby Jagi, herod baby), dziecka (dzieciny, dzieciaka, dzieciątka, dzieciucha) i tysięcy innych wyrazów oraz ich pochodnych.

Spytajmy wprost: czemu służy stereotypowość w toku komunikowania? Nasuwa się odpowiedź, że w pierwszej kolejności ujednoznacznieniu treści danego przedstawienia. Upraszcza przekaz, czyniąc zawarte w nim wyobrażenie tyleż płytkim, co łatwo przyswajalnym. Zachodzi tu ważna kwestia o charakterze kognicyjnym i antropokulturowym. Generalnie stereotypowość można zdefiniować jako określone nacechowanie sposobu postrzegania, ujmowania i przedstawiania rzeczywistości, za każdym razem zmierzające do jej oswojenia, uproszczenia i ocennego uschematyzowania.

Na stereotyp składa się kulturowo utrwalone wyobrażenie społeczno-językowe wraz ze skojarzeniem, jakie ewokuje. Konstrukcje znakowe tego rodzaju, uczestnicząc w indywidualnym i zbiorowym procesie przetwarzania informacji, preferują "gotowe” rozpoznanie kosztem poznania. Każda z nich komunikuje wiązkę asumpcji: obiegowe „niczyje” poglądy, myśli, przeświadczenia, mniemania, przesłanki. Utożsamia cudze z własnym. Powiela i utrwala zbiorowe przekonania. Powszechność występowania stereotypu w funkcji widma semantycznego czyni go nieodzownym elementem podmiotowej kompetencji porozumiewających się stron.

Wszystkie stereotypy, sprowadzone do swej funkcjonalnej podstawy, stanowią rodzaj „gotowca”, podręcznej „ściągi”, która podsuwa adresatowi prosty wzór na orientację, podpowiadając, jak postrzegać, przeżywać, odczuwać i co myśleć o rzeczywistości. Na pozór nic w tym złego. Oprócz tego mamy jednak coś jeszcze: zakomunikowane w strukturze głębokiej stereotypowego przekazu spozycjonowanie, a wraz z nim oswojenie przestrzeni i ukrytą perswazją (koncepcja Vance'a Packarda). Orientuj się, oto twoje miejsce, wskazana lokacja, dzięki której już się nie zgubisz „wśród swoich”.

W dowolnym wyrażeniu udział stereotypu staje się niewidzialną stroną jego semantyki. Nietrudno w tym przypadku o przekroczenie zielonej granicy między perswazją a manipulacją. Zapewne to miał 
na myśli znakomity francuski semiolog Roland Barthes, formułując przed laty następującą przestrogę: „W każdym znaku drzemie owo monstrum - stereotyp". Perfidnie wykorzystany do celów manipulacji, stereotyp staje się uczestnikiem już nie dyskursów ideologicznych i polemik światopoglądowych, lecz pospolitego judzenia jednych przeciw drugim i nienawistnego hejtu.

Wyrażając określone przekonanie/pogląd bądź któreś z powszechnie przyjętych i uznawanych za bezdyskusyjnie prawdziwe przeświadczeń, stereotypy tak czy inaczej respektują i urzeczywistniają prymarny podział „my - wy”. W polu semantycznym ich oddziaływania obraz świata i dostarczany zasób wiedzy o nim ulega symplifikacji, polaryzując się i dzieląc na dwie biegunowo przeciwstawne części: 'naszą' (znajomą, swojską) i 'obcą' (odrzucaną przez daną wspólnotę).

Pociąga to za sobą istotne konsekwencje gnoseologiczne oraz aksjologiczne. Przedstawiana rzeczywistość schodzi na daleki plan; nie ona bowiem jest w świetle danego stereotypu najważniejsza. Ważna jest wyłącznie jej zamienna reprezentacja. W świetle wyobrażenia i przedstawienia, które dany stereotyp w sobie zawiera, cała dająca się pomyśleć rzeczywistość bądź jej aktualnie istotny dla komunikujących się podmiotów fragment trwale ulega rozszczepiającemu podziałowi.

Pod działaniem stereotypów (a częstokroć pod ich przemożną presją) następuje polaryzacja uznawanego przez daną zbiorowość poglądu i osądu. Wraz z nią tworzy się środowisko komunikacyjne sprzyjające różnego typu manipulacji. Dwuwartościowa optyka postrzegania sprawia, iż najbliższe otoczenie i cały świat dzieli się na to, co powszechnie przyjęte i wspólnie akceptowane, i to, co w niej nieakceptowane, „inne” (odrzucone). Konstrukcja stereotypu opiera się na niewzruszonych pewnikach. Wyposażeni w stereotyp wiemy, jak jest, wiemy to samo, co inni, z którymi się utożsamiamy. Reszta nas nie obchodzi.

Stereotyp narzuca schemat poznawczy, oduczając jednostkę i zbiorowość nie tylko myślenia, ale i zbędnego (wiemy przecież, jak jest) kontaktu $\mathrm{z}$ jakąkolwiek empirią. Nie liczy się indywidualne doświadczenie rzeczywistości, które stanowiłoby argument i probierz weryfikujący pospólne mniemanie. Liczy się samo przeświadczenie, przekonanie co do niej. Co więcej, to ono jako wytworzony i utrwalony wspólny pogląd i osąd samo w sobie staje się quasi-rzeczywistością.

Porządek przestrzeni społecznej ujęty w stereotyp zamyka ją w ciasnych granicach przyjętego przez daną zbiorowość poglądu, będącego dla niej niepodważalnym („rudzielce są fałszywi”, „Szkoci są skąpi”, „koty to dranie”, „polnische Wirtschaft”, „dumb blond”, „Arab = terrorysta”, „Włosi to marni żołnierze” etc.) aksjomatem. Jak rozpoznać genezę tego fenomenu? Wiąże się on nader często z uprzedzeniem. Stereotyp twardo broni raz zajętego miejsca w umysłach i okopuje się na swoich pozycjach. „Jak świat światem, nie będzie Niemiec Polakowi bratem”. 
Nie ma jednak stereotypów niezmiennych i raz na zawsze ustalonych. „Dobry Indianin to martwy Indianin” - powiadali niegdyś zdobywcy kolonizujący Amerykę. Na kartach powieści o Dzikim Zachodzie i w setkach ekranowych westernów „czerwonoskórym” niezmiennie przypadała rola czarnych charakterów: podstępnych wrogów białego człowieka, nieokrzesanych dzikusów, alkoholików i wykolejeńców, wojowniczych członków groźnego plemienia agresorów (Komancze), perfidnych napastników znienacka atakujących pocztowe dyliżanse i tabory traperów.

Owszem, w obiegu kultury popularnej zdarzały się niekiedy szlachetne wyjątki (legendarny Cochise, znachor Inczuczuna, młody wódz Apaczy Mescalero Winnetou). Stereotypowy obraz „złego Indianina” utrzymywał się jednak nie tylko wśród samych Amerykanów bardzo długo, ulegając powolnej erozji, i dopiero całkiem od niedawna ustępując miejsca przedstawieniom Indian jako prawowitych mieszkańców wyzutych z własnej ziemi, ofiar bezwzględnej i okrutnej kolonizacji.

Pierwszemu z omawianych wyobrażeń przypadł istotny udział w długofalowym, XIX- i XX-wiecznym makroprocesie formowania się amerykańskiej tożsamości. Drugie z nich - diametralnie od tamtego różne - przyczynia się do współczesnej dekonstrukcji i rewizji zbiorowego spojrzenia na historię Ameryki. Aby jednak mogła ona nastąpić, konieczne było zakwestionowanie i porzucenie tamtych negatywnych przedstawień.

W stereotypach kondensuje się zła bądź dobra (ciemna i jasna) pamięć emocjonalna przekazu, jaki w sobie zawierają. Jej zapis powstaje w wyniku leksykalizacji lub frazeologizacji znaczenia leżącego u podstaw konstrukcji danego stereotypu. W swym polu semantycznym pojęcie 'żołnierz' („dziewczynie nie skłamie”) rozszczepia się w podziale skojarzeń: $\mathrm{z}$ jednej strony na żołdaka, sołdata, trepa, także na gangstera najniższego w hierarchii gangu, z drugiej - na żołnierzyka, wojaka, wiarusa (Stary Wiarus), towarzysza broni etc.

Stereotyp z zasady swego funkcjonowania nie przedstawia samej rzeczywistości, lecz tylko powiela i replikuje określony osąd i obiegowe przekonanie na jej temat. Wszelako nie oznacza to, iż pozostaje on zawsze mylny czy fałszywy. W punkcie wyjścia, w momencie formowania się danego stereotypu następuje proces krystalizacji określonego wyobrażenia uznanego przez zbiorowość za pogląd oczywisty i powszechnie obowiązujący.

Należy mieć na uwadze, iż nie wszystkie ustereotypowione wyobrażenia są fałszywe. Ich modelunek sprawia, że zawsze upraszczają, ale nie zawsze falsyfikują rzeczywistość. Bywają takie, które trafnie opisują kogoś lub coś i wyrażają celny osąd. Stereotyp kursujący w obiegu społecznym staje się groźny dopiero jako powszechnie obowiązujący w danej wspólnocie dogmat. Mundus vult decipi. Bywa wówczas niezmiernie niebezpieczny, gdyż, niosąc z sobą określone powszechnie przyjęte i uznane za prawdziwe wyobrażenie i komunikując jakiś prze- 
sycony emocjami pogląd, kreuje iluzję swej prawdziwości i wprowadza ludzi w błąd.

Wynika z tego, że mamy do czynienia z aspektem procesu semiozy - teraz i w dowolnie odległej przeszłości historycznej powszechnie występującym, niezmiernie doniosłym i istotnym społecznie w funkcjonowaniu zarówno jednostki, jak i zbiorowości. Nie wynika natomiast, iż stereotypowość i stereotyp są z natury złe, choć z drugiej strony wiadomo, że poszczególne stereotypy wykorzystywane do falsyfikowania przedstawień i relacji o świecie częstokroć takie bywają. Stereotyp czerpie z otoczenia, bierze $\mathrm{z}$ niego dla siebie pożywkę i - arbitralnie generalizując jednostkowe i zbiorowe obserwacje - narzuca je i komunikuje w formie powszechnie przyjmowanego i uchodzącego za niekwestionowaną prawdę uogólnienia. To z kolei czyni fenomen stereotypowości wszelkich znakowych przedstawień kwestią o zasadniczym znaczeniu dla mikro- i makrospołecznego obiegu informacji o świecie: zarówno w jego zamierzchłych i całkiem niedawnych dziejach, jak i w bieżącej, napływającej z każdym dniem aktualności.

Nieustanne zainteresowanie badaczy rozmaitych dyscyplin i reprezentantów różnych orientacji metodologicznych stereotypami: ich morfologią, życiem społecznym, pełnionymi w nim funkcjami, powstawaniem, rozwojem, trwaniem i zanikiem, warto uznać za jedną z podstawowych powinności nauk humanistycznych.

\section{Pole znaczeniowe}

Najpierw przeprowadźmy rekonesans etymologiczny. Greckiego pochodzenia wyraz 'stereotyp' jest złożeniem. Pierwszy z komponentów objaśnia drugi. Greckie 'týpós' i łacińskie 'typus' znaczy wzorzec, model, ale także reprezentację, odbicie, obraz. Wyróżniający stereotyp przedrostek 'stereo-' zasługuje na specjalną uwagę. W swym języku macierzystym ma dwa znaczenia, z których każde wnosi cenną wartość do naszych rozważań. W pierwszym znaczeniu 'stereo' oznacza twardość, utrwalenie, stabilność, niezmienność, w drugim natomiast sygnuje przestrzenność, umiejscowienie i trwałe osadzenie w przestrzeni.

Stereotyp jako relacja funkcjonalna steruje ludzkim umysłem poprzez uogólnienie. Wiadomo nie od dzisiaj, że każdy bez wyjątku stereotyp jest wyrażeniem utwardzonym, rodzajem skamieliny semantycznej zastygłej w czasie. Procesy morfologiczne, którym podlega, są zawsze konkretnie umiejscowione, to znaczy dzieją się w określonej przestrzeni komunikowania.

W aspekcie poznawczym jako obiekt interesujący badacza stereotypy występują $\mathrm{w}$ dwoistej postaci, a mianowicie w tekstach/komunikatach/przekazach oraz w ludzkich umysłach: w pospólnie przyjętym przez daną zbiorowość i uznanym za własny systemie wartości, wizji świata, mechanizmach jego postrzegania oraz funkcjonowania w określonych realiach. 
Nie ma stereotypów obojętnych czy też całkiem neutralnych. Pole znaczeniowe każdego stereotypu wytwarza i kryje w sobie napięcie między tym, co referencyjnie neutralne, a tym, co perswazyjnie bądź manipulatorsko nieobojętne w użyciu języka, eo ipso w relacji zachodzącej między podmiotem a podmiotem wokół określonego pojęcia. Owo „pomiędzy” stanowi kolejny przestrzenny aspekt funkcjonowania stereotypu w systemie komunikacji społecznej.

Stereotypizacja znaku czy wyrażenia językowego nie dokonuje się w jednej chwili. Proces ten przebiega stopniowo. Stereotyp jako jego wytwór niczym stalaktyt bądź stalagmit odkłada się w postaci semantycznego nacieku.

Stereotyp ustanawia i podtrzymuje taki aspekt znaczenia przekazu, który schematyzuje i petryfikuje zawarte w nim przedstawienie. Uznawane jest ono przez przekonaną co do tego jednostkę i zbiorowość, z którą się ona utożsamia, za bezdyskusyjnie prawdziwe, to znaczy zgodne z rzeczywistością.

W przestrzeni społecznej przynależnej danej wspólnocie residuum i stanem naturalnym przedstawień stereotypowych pozostaje inercja znaku i znaczenia. Nie ustalenie od nowa znaczenia, lecz jego zastany bezwład. Nie należy go zatem utożsamiać ani mylić z udziałem konwencji (umowy językowej) organizującej każdy proces komunikowania i porozumiewania się. To dwie różne sprawy.

Konwencja pojmowana jako umowność sposobu przedstawiania jest nieodzowna w procesie komunikowania. Utrzymuje ona znak w stanie gotowości do wykreowania i uniesienia określonego znaczenia. Od nowa. Inaczej niż stereotyp. Ten więzi jednostkową i zbiorowa wyobraźnię. Zbieżność pojęciowa między nimi polega na tym, iż w ramach danej wspólnoty akceptowany przez nią stereotyp czy zbiór stereotypów nabiera właściwości powszechnie obowiązującej konwencji. Neutralny semantycznie rzeczownik języka niemieckiego Wirtschaft w połączeniu z neutralnym przymiotnikiem polnische daje silnie nacechowane, naznaczone negatywnym stereotypem wyrażenie polnische Wirtschaft.

Ze stereotypami jesteśmy za pan brat, są czynnikiem stale obecnym w środowisku komunikowania się. Umiejętność, co więcej, zażyłość ciągłego współistnienia z nim i z nimi człowiek nabywa całkiem bezwiednie w wieku najmłodszym. Dzieci z reguły szybko się uczą. Świat dziecięcy, choć wydaje się bezkresny i otwarty, zna od samego początku dorastania jednostki generalny podział na: znajome vs nieznane, bezpieczne vs niebezpieczne, rozpoznane vs nieczytelne, pojmowalne vs niepojęte.

$\mathrm{W}$ procesie wychowania $\mathrm{z}$ udziałem dorosłych dziecko nabywa spontanicznej zdolności rozpoznawania i reagowania na wszelki czynnik zagrożenia. Kultura wspomaga w tym naturę. Doskonale widać to na przykładzie percepcji pełnego stereotypowych przedstawień wyobrażonego świata bajek i baśni. To wtedy jedna po drugiej kodują się 
w ludzkim umyśle odciśnięte głęboko w podświadomości memy - matryce postrzegania, których integralny element stanowi stereotyp.

\author{
Kłopoty \\ ze stereotypem
}

[2] Zob. G. Grochowski, Stereotypy - komunikacja -

literatura, „Przestrzenie Teorii” 2003, nr 2, s. 49-71.
Pierwszy kłopot badawczy stanowi migotliwość samego pojęcia. Od dość dawna zadomowione w języku potocznym, funkcjonuje ono $\mathrm{w}$ wielu różnych kontekstach i rozmaitych znaczeniach. Przed laty zwrócił na to uwagę Grzegorz Grochowski, dając w swych literaturoznawczo-językoznawczych rozważaniach dotyczących zagadnienia stereotypu przykład styku - wydawać by się mogło - całkiem naturalnego ze względu na bliskie powinowactwo łączące obie dyscypliny, zwłaszcza zaś z uwagi na tożsamość tworzywa znakowego.

Chodzi mianowicie o istnienie rozbieżności dającej o sobie znać nie tyle w zakresie stosowanych metod, ile bardziej oczekiwanych i osiąganych celów badawczych. W przywołanym artykule mowa jest o zasadniczej różnicy między spojrzeniem na obecność i funkcję stereotypu, z jakim mamy do czynienia na dwóch bezpośrednio stykających się z sobą polach badawczych: $\mathrm{z}$ jednej strony stereotyp jako obiekt badań w ujęciu językoznawcy (dla którego jego występowanie stanowi zwykle poznawczy punkt dojścia), z drugiej natomiast ten sam, wydawać by się mogło, fenomen odmiennie postrzegany i rozpatrywany przez literaturoznawcę (który w prowadzonych przez siebie badaniach dzieł literackich $\mathrm{z}$ reguły odkrywa i konstatuje istnienie stereotypu i traktuje dostrzeżone przejawy jego funkcjonowania jako punkt wyjścia do dalszych rozważań) [2].

Kłopot drugi bierze się z multidyscyplinarnego rozparcelowania zarówno klasycznej (Descartes, Pascal, Leibniz, Locke, Humboldt i inni), jak i przede wszystkim współczesnej, w tym również najnowszej, refleksji badawczej nad stereotypami i ich funkcjami społeczno-kulturowymi. Otóż, nie jest to tylko istotna skądinąd kwestia samego przypisania problematyki naukowej do jakiejś jednej dziedziny, lecz o wiele szerszy problem ustanowienia badawczego modus operandi.

Mowa o scalającym - integrującym całokształt różnych aspektów zjawiska - ogarnięciu i traktowaniu problematyki stereotypu, dzięki któremu możliwy stałby się, choćby tylko w miarę spójny, niezmiernie dzisiaj potrzebny, metadyscyplinarny dyskurs wokół wspólnego przedmiotu badań (vide: kłopot pierwszy). Mnogość istniejących perspektyw poznawczych nie oznacza w tym przypadku embarras de richesse. Natomiast ewentualne zawłaszczenie problematyki stereotypu przez którąkolwiek z nauk, dyscyplin czy specjalności prowadziłoby nieuchronnie do zmonopolizowania danego punktu widzenia z oczywistą szkodą dla dalszego rozwoju naukowych studiów nad tym fenomenem.

Dylemat trzeci, kto wie czy nie najważniejszy, dotyczy zaprojektowania i uzgodnienia możliwie najbardziej nośnej i użytecznej pod względem operacyjnym definicji stereotypu jako wielorako użytecznego terminu naukowego. To warunek sine qua non - bez dwóch zdań. 
Oznacza bowiem właściwe bądź niewłaściwe określenie przedmiotu badań wraz z ich adekwatną metodologią. A jednak dotychczasowe próby podejmowane w tej kwestii nie były zbyt liczne, w odróżnieniu od rozmaitych wybiegów i uników mających na celu jej ominięcie (widocznych jak na dłoni między innymi w klasycznej książce Waltera Lippmanna[3]).

Klasyczna na gruncie polskim koncepcja stereotypu definiuje to pojęcie ze stanowiska filozofii. Przytaczam ją w skrócie: „Przez słowo stereotyp rozumiemy sąd wartościujący (negatywnie lub pozytywnie) połączony z przekonaniem [...]"[4]. Ma słuszność jej autor Adam Schaff, gdy łączy stereotyp z działaniem ludzkim; nie ma, gdy - sztucznie zawężając zakres powszechnie dostępnej empirii - twierdzi, że stereotypy istnieją tylko w postaci werbalnej.

Uważne przestudiowanie i rozpatrzenie szeregu różnorodnych propozycji definicyjnych, $\mathrm{z}$ jakimi mamy do czynienia $\mathrm{w}$ rodzimej i obcojęzycznej literaturze przedmiotu, skłania do wniosku, że najbardziej obiecujące horyzonty poznawcze przed badaczem otwiera szeroko zakrojone semiotyczno-lingwistyczne ujęcie definicji stereotypu. Jej szczególnie nośną wersję zaproponował blisko ćwierć wieku temu polski lingwista i etnolog Jerzy Bartmiński. Sformułowana przez niego robocza eksplikacja terminu 'stereotyp' brzmi następująco:

Wyobrażenie przedmiotu obejmujące zarówno cechy opisowe, jak i wartościujące obraz, oraz będące rezultatem interpretacji rzeczywistości w ramach społecznych modeli poznawczych. To rozumienie stereotypu uwzględnia zarówno aspekt semantyczny, jak i formalny, nie przeciwstawia stereotypów językowych (formalnych) stereotypom mentalnym, raczej - przeciwnie - łączy je w możliwie szerokim zakresie. Stereotyp możemy badać jako ustabilizowane (reprodukowane z pamięci) połączenie semantyczne i/lub formalne, stereotypizacja obejmuje bowiem płaszczyznę semantyczną języka (tę w pierwszej kolejności) i formalną[5].

Zaletą powyższej eksplanacji jest jej otwarcie na najszerzej pojętą problematykę komunikacyjną. Zaproponowana perspektywa mieści w sobie bardzo szerokie spektrum zagadnień dotyczących udziału stereotypowości i stereotypizacji przedstawień. Ze względu na powszechność występowania i różnorodność dziedzin życia, form komunikowania oraz środków przekazu opowiadam się tutaj za koncepcją wieloaspektowego, interdyscyplinarnego charakteru pojęcia stereotypu. Żadna $\mathrm{z}$ dyscyplin naukowych nie może sobie rościć prawa do wyłączności badań na stereotypem, a kwestia „pierwszych skrzypiec” w orkiestrze i chwilowego prymatu wyników osiągniętych przez którąkolwiek powinna być pochodną konkurencji między nimi, prowadzącej

[3] W. Lippmann, Public Opinion, New York 1956. [4] A. Schaff, Stereotypy a działanie ludzkie, Warszawa 1981, s. 115.

[5] J. Bartmiński, Podstawy lingwistycznych badań nad stereotypem - na przykładzie stereotypu matki,

\section{Wokół definicji}

[w:] Stereotyp jako przedmiot badań lingwistycznych. Teoria, metodologia, analizy empiryczne, „Język i Kultura" t. 12, red. J. Anusiewicz, J. Bartmiński, Wrocław 1998, s. 64. 
do coraz lepszych efektów poznawczych. W ostatecznym rezultacie liczy się bowiem synergia podejmowanych wysiłków. Wspólnie możemy osiągnąć najwięcej.

Pośród dziedzin szczególnie zainteresowanych złożoną problematyką stereotypu, stereotypowości i stereotypizacji w odniesieniu do wszelkiego typu przedstawień językowych należy wymienić w pierwszej kolejności: lingwistykę, semiotykę, kognitywistykę, logikę formalną, socjologię (wraz z teorią i praktyką odgrywających nie od dzisiaj doniosłą rolę badań opinii publicznej), psychologię społeczną, historię sztuki, naukę o literaturze, filmoznawstwo, medioznawstwo, filozofię (poczynając od ontologii, epistemologii i gnoseologii, poprzez logikę formalną, aż do aksjologii, etyki i estetyki), pedagogikę, etnolingwistykę i antropologię kulturową i, last but not least, naukę o komunikacji.

Nie znaczy to, że lista dziedzin i specjalności naukowych zainteresowanych pod różnym kątem problematyką stereotypu została w niniejszym przeglądzie wyczerpana i zamknięta. Z całą pewnością nie. Oprócz wymienionych akces badawczy do niej mogą w każdej chwili zgłosić również inne - zarówno nowe, jak i uprawiane od dość dawna - dyscypliny, by przywołać tylko przykładowo tak odmienne z nich, jak: statystyka, topologia, nauka o komunikowaniu czy politologia (ze szczególnym akcentem położonym na teorię i praktykę dyplomacji).

Stereotyp w przestrzeni społecznej
Stykamy się z nim na każdym kroku i wszędzie go pełno. Podchodząc realistycznie: polimorficzność najróżniejszych lingwistyczno-kulturowych procesów stereotypizacji, z którymi, podobnie jak nasi poprzednicy, lecz w nieporównanie intensywniejszy niż to miało miejsce kiedyś sposób, mamy na co dzień do czynienia w życiu społecznym, należy uznać za zespół praktyk powszechnie występujących we współczesnej infosferze. Stereotypowe użycia znaków - zarówno werbalnych, jak i pozawerbalnych - przybierają w niej obecnie niezmierzoną mnogość najróżniejszych postaci.

Polimorficzność dawnych i nowych form stereotypów nie jest argumentem przemawiającym za rezygnacją i nieużywaniem terminu 'stereotyp' jako nazbyt wieloznacznego i przez to mylącego. Wprost przeciwnie, ze względu na lawinowy rozrost, rozległość i tyleż globalną, co lokalną skalę powszechności występowania zjawiska, a także różnorakie skutki komunikacyjne, jakie ono co rusz wywołuje, pojęcie 'stereotyp' zyskuje na znaczeniu. Z tym, że sam fenomen stereotypizacji domaga się szerokiego spojrzenia badawczego, pozwalającego ogarnąć rozmaite dylematy i problemy z niej wynikające.

Stereotyp, choć złożony ze znaków, nie jest pojedynczym leksemem, choć tak się go najczęściej ujmuje. Nie wchodzi on też, co istotne, w skład systemu danego języka. Przynależy natomiast do natury wszelkiego komunikowania. Znaczy to, iż powołuje go do istnienia i przypisuje określoną funkcję semantyczną usus językowy. Można powiedzieć, iż stereotyp jako element komunikowania dostarcza jego użytkownikom pojęć w innym niż słownikowy stanie rzeczy, oscylując 
między powszechnym przekonaniem a ustaloną prawdą uznawaną za "swoją" przez daną wspólnotę i zbiorowość.

Nie tylko przez swoją permanentną obecność w polu zainteresowania wielu dziedzin naukowo-badawczych, ale przede wszystkim ze względu na uprzednio wskazane zróżnicowanie funkcji, jakie stereotyp pełni w życiu społecznym, należy on - podobnie jak na przykład narracja, obraz, znaczenie czy tekst kultury - do klasy pojęć wyposażonych w szczególnie wysoki stopień użyteczności i nośności poznawczej. Nadaje mu to wart podkreślenia walor uniwersalności operacyjnej wielorako pomocnej i przydatnej, jeśli nie wręcz nieodzownej, we współczesnej refleksji humanistycznej.

Studium poniższe od początku zmierza do zaproponowania poszerzonego, makrosystemowego modelu społecznego funkcjonowania stereotypu, w którym mieści się i współgra gama różnych tekstów kultury, procesów kognicyjnych i zjawisk psychospołecznych zazwyczaj niełączonych z sobą, a niekiedy nawet wzajemnie się wykluczających. Łącznikiem między nimi wszystkimi staje się relacja między przestrzenią symboliczną danej kultury a procesami komunikowania, jakie w niej zachodzą.

W makrosystemie kultury współczesnej koegzystują z sobą byty i teksty bardzo zróżnicowane. Zarówno aforyzm, przysłowie, dowcip, satyra literacka, szopka noworoczna, paszkwil, wyzwisko, obelga, horoskop (wraz z charakterystykami znaków zodiaku) i powieść, jak i portret rysunkowy bądź malarski, karykatura, fotografia, film, piosenka, reklama $z$ będącym jej integralną cząstką sloganem, gra elektroniczna, fake news czy mem internetowy etc. W każdym $\mathrm{z}$ wymienionych rodzajów komunikatu czy, jak kto woli, przekazu kulturowego, a także w wielu innych jego postaciach, formach, gatunkach i odmianach gatunkowych, z różną intensywnością, lecz zauważalnie dają o sobie znać: stereotyp, stereotypowość i stereotypizacja. Tworzą one wspólnie intersemiotyczne i międzykulturowe iunctim, za sprawą którego bardzo różne zbiory form komunikowania mogą być - mimo odmienności medium oraz wielu innych dzielących je różnic funkcjonalnych - z pożytkiem opisywane, analizowane i interpretowane.

Z tego właśnie - ważnego dla całości przedstawianej tu koncepcji - powodu celowo nie ograniczałem się do przywoływania egzemplifikacji na przykład wyłącznie filmowej, z premedytacją sięgając po bardzo zróżnicowane przykłady stereotypu czerpane z różnych dziedzin życia, z odmiennych systemów językowych tudzież alternatywnych względem siebie gatunków i stylów komunikowania oraz środków przekazu.

Dzieli je użyte tworzywo, wykorzystany system językowy i określona w danej czasoprzestrzeni kultura przedstawień symbolicznych: werbalna, pozawerbalna, ikoniczna, werbalno-ikoniczna, muzyczna, audialna, kinematograficzna, audiowizualna etc. Łączy natomiast stadność powielenia, dzięki której zastygłe w czasie matryce zbiorowych wyobrażeń replikują się w przestrzeni społecznej, podtrzymując przez długie lata, a nawet wieki integrującą daną wspólnotę wszechobecność danego stereotypu. 
Nie znaczy to bynajmniej, że rozmaite sfery komunikowania zostały całkowicie z sobą utożsamione. Przestrzegając i pilnując ich dystynkcji, nie wolno jednak gubić z pola widzenia polimorficznej uniwersalności tego zjawiska, które daje o sobie znać w bardzo różnych procesach komunikacji. Taką płaszczyznę, zdolną uniwersalizować refleksję badawczą nad problematyką stereotypu, stanowią właśnie jego funkcje i udział w przestrzeni symbolicznej i komunikowaniu.

Owszem, opisując i analizując stereotypy, nie zapominamy o zróżnicowaniu materiału językowego, form ekspresji i alternacji kursowania w ramach odmiennych obiegów. Ich wspólny mianownik funkcjonalny w każdym z poszczególnych przypadków stanowi jednak to, że wszystkie owe przedstawienia i wyobrażenia, jakie występują w przebiegu (resp. akcie) komunikacji, operują na własny użytek czynnikiem stereotypowości i stereotypizacji, bezumownie wykorzystując do tego wielki kwantyfikator.

Stereotypy zabudowują przestrzeń symboliczną zbiorowości, która je akceptuje i bezkrytycznie im ulega. Czytanie świata, choć niewątpliwie łatwiejsze przez zabieg ujednoznacznienia, w życiu pojedynczego człowieka i grupy społecznej (rodziny, klanu, kasty, warstwy, klasy, wspólnoty narodowej itp.), do której przynależy i z którą się identyfikuje, ulega mniej lub bardziej zaawansowanej schematyzacji, ergo atomizującej rzeczywistość degradacji jej obiegowych wyobrażeń.

Nasuwają się pytania: jak dekonstruować szkodliwe dla życia społecznego stereotypy? Jak je rozbrajać? Sklejenie na powrót naszpikowanego nimi niczym pole minowe świata uwikłanego w niewolę stereotypowych wyobrażeń jest, co prawda, bardzo trudne, lecz po spełnieniu pewnych warunków możliwe. Droga do tego celu wiedzie przez jednostkową i zbiorową katharsis, polegającą na ponownym odkryciu przez człowieka rzeczywistości i oczyszczającym doświadczeniu jej prawdziwych, a nie domniemanych właściwości.

W tym sensie stereotyp jako element procesu komunikowania należy na równi do sfery komunikacji werbalnej, jak i niewerbalnej, co w przypadku przedstawień ikonicznych, kinematograficznych etc. ma szczególnie doniosłe znaczenie. Słowo w funkcji kontrapunktu poznawczego jest bowiem zdolne weryfikować obraz, podobnie jak pojedynczy obraz czy strumień ruchomych obrazów zaświadcza na różne sposoby o prawdziwości lub fałszywości danego przekazu werbalnego.

Stereotypy występują w naszym życiu w wielu odmiennych postaciach i obiegach społecznych. Wskazując na generalną jednorodność pełnionych funkcji, należy zachować świadomość ich heterogenicznego charakteru oraz wielorakości kontekstów, w jakich występują. Nieporównanie ważniejsza od jednorodności i „czystości” użytej egzemplifikacji okazuje się jednak uniwersalność występowania tego fenomenu w najróżniejszych dziedzinach współczesności w połączeniu z wyzwaniami poznawczymi, jakie stawia on nie tylko przed badaczami, ale także każdym z nas jako zanurzonym w codzienności uczestnikiem aktów komunikacyjnych. 
Allport G.W., The Nature of Prejudice, Boston 1954

Aronson E., Człowiek - istota społeczna, przeł. J. Radzicki, Warszawa 1998

Bertalanffy L. von, Ogólna teoria systemów, przeł. E. Woydyło-Woźniak, Warszawa 1984

Bokszański Z., Stereotypy a kultura, Wrocław 2001

Dijk Th.A. van, Prejudice in Discours. An Analysis of Ethnic Prejudice in Cognition and Conversation, Amsterdam-Philadelphia 1984

Grochowski G., Stereotypy - komunikacja - literatura, „Przestrzenie Teorii” 2003, nr 2, s. 49-71

Hołówka T., Myślenie potoczne. Heterogeniczność zdrowego rozsądku, Warszawa 1986

Jakobson R., W poszukiwaniu istoty języka, t. 1-2. Wybór i red. M.R. Mayenowa, Warszawa 1989

Keil F., Concepts, Kinds and Cognitive Development, Cambridge, Mass., 1989

Kushner H.S., When Bad Things Happen to Good People, London 1982

Langacker R.W., Concept, Image and Symbol. The Cognitive Basis of Grammar, Berlin 1990

Leibniz G.W., Nowe rozważania dotyczace rozumu ludzkiego, przeł. I. Dąmbska, Warszawa 1955

Lippmann W., Public Opinion, New York 1956

Locke J., Rozważania dotyczące rozumu ludzkiego, przeł. B.J. Gawecki, Warszawa 1955

Mitosek Z., Literatura i stereotypy, Wrocław 1974

Putnam H., Mind, Language and Reality, Cambridge 1975

Sapir E., Kultura, język, osobowość. Wybrane eseje, przeł. B. Stanosz, R. Zimand, Warszawa 1978

Schaff A., Stereotyp: definicja i teoria, „Kultura i Społeczeństwo” 1978, nr 3

Schaff A., Stereotypy a działanie ludzkie, Warszawa 1981

Sperber D., Wilson D., Relevance: Communication and Cognition, Oxford 1986

Stereotypy w literaturze (i tuż obok), red. W. Bolecki, G. Gazda, Warszawa 2003

Whorf B.L., Język, myśl i rzeczywistość, przeł. T. Hołówka, Warszawa 1982

Wierzbicka A., Semantyka. Jednostki elementarne i uniwersalne, przeł. A. Głaz, K. Korżyk, R. Tokarski, Lublin 2010

Wojciszke B., Psychologia społeczna, Gdańsk 2019

Wojciszke B., Teoria schematów społecznych. Struktura i funkcjonowanie jednostkowej wiedzy o społecznym otoczeniu, Wrocław 1986 